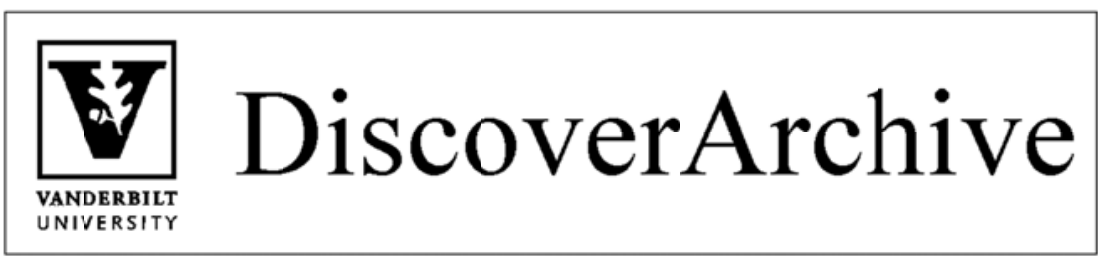

Retrieved from DiscoverArchive,

Vanderbilt University’s Institutional Repository

This work was originally published as Ingrid Brunk Wuerth, Transnationalizing Public Law, in 10 German Law Journal 13372009. 


\section{HEINONLINE}

Citation: 10 German L.J. 13372009

Content downloaded/printed from

HeinOnline (http://heinonline.org)

Tue Aug 28 11:10:27 2012

-- Your use of this HeinOnline PDF indicates your acceptance of HeinOnline's Terms and Conditions of the license agreement available at http://heinonline.org/HOL/License

-- The search text of this PDF is generated from uncorrected OCR text.

-- To obtain permission to use this article beyond the scope of your HeinOnline license, please use:

https://www.copyright.com/ccc/basicSearch.do?

\&operation $=$ go\&search Type $=0$

\&lastSearch $=$ simple\&all=on\&titleOrStdNo=2071-8322 


\title{
Transnationalizing Public Law
}

\author{
By Ingrid Wuerth
}

Many warm thanks for the opportunity to participate in this seminar honoring the German Law Journal. I am especially pleased to be addressing you here at the Free University, which generously hosted my stays in Berlin as both a Humboldt and a Fulbright Scholar.

Let me begin by extending my best wishes and congratulations to Russell Miller and Peer Zumbansen on the $10^{\text {th }}$ Anniversary of the German Law Journal. I would also like to thank them for service the Journal provides to the academic community. We heard yesterday from many German readers of the Journal who felt that it provided an important service in German legal circles, which, I must confess, I had not entirely anticipated or appreciated. Perhaps I can speak for the American and other largely English speaking readers in saying that the Journal is an invaluable way to keep abreast of legal developments in Germany. It performs admirably this perhaps more quotidian task of furnishing timely, yet in-depth articles about Germany to those of us situated outside the country. This really is an important public service, and again you have my thanks.

I am tasked today with talking about transnationalization, in particular the question of whether public law in the United States is undergoing some process of transnationalization today. My response, based on the work of the U.S. Supreme Court is yes, although probably only in a thin sense. The starting point for discussing this issue is generally the Supreme Court's citation to the laws of other countries in Printz v. United States, ${ }^{1}$ Roper $v$. Simmons, ${ }^{2}$ and Lawrence $v$. Texas. ${ }^{3}$ But these examples of comparative public law are controversial, substantively weak in the case of Printz, and relatively case (or issue) specific. It is somewhat unclear how significant the comparative aspects of the opinion were to the holding. Serious problems arise, moreover, in deciding which countries serve as useful benchmarks for comparison. My guess - and it is only that - is that we won't see the U.S. Supreme Court moving much further in this direction.

\footnotetext{
"Professor of Law \& Director of International Legal Studies Program, Vanderbilt University Law School. Ingrid.wuerth@vanderbilt.edu.

${ }^{1} 521$ U.S. 898 (1997) (Breyer, J. dissenting) (federalism).

${ }^{2} 543$ U.S. 551 (2005) (juvenile death penalty).

${ }^{3} 539$ U.S. 558 (2003) (anti-sodomy laws).
} 
There is, however, another form of transnationalization that is part of the Court's broader engagement with war and with international law over the half decade or so. In cases like Sosa v. Alvarez-Machain, ${ }^{4}$ Boumediene v. Bush, ${ }^{5}$ Sanchez-Llamas v. Oregon, ${ }^{6}$ and Medellin $v$. Texas, ${ }^{7}$ the Court has engaged with the domestic legal systems of other countries. But this engagement has been thin in three ways. First, the discussions of transnational law have been short and sometimes cursory. Second, by and large (with the exception of Boumediene), this engagement with foreign legal systems is driven by questions of international law, rather than domestic constitutional law. Finally, it is Congress, at one level or another, that forced the Court's engagement with international law in the first place. So, while I do think these are important examples of transnationalism, they provide no clear path toward an expansive use of comparative materials in constitutional law generally.

In Sosa, the Court concluded that the Alien Tort Statute allowed U.S. federal courts to recognize certain claims based on customary international law as part of federal common law. Determining the content of customary international law requires courts to consider the legal landscape of other countries - in particular, whether the conduct in question is prohibited in other countries, and whether the prohibition stems for a sense of legal obligation. For these reasons, the Court looked, for example, at a variety of national constitutions to determine whether the arbitrary detention at issue violated customary international law. ${ }^{8}$ Applying an exhaustion requirement in ATS cases might similarly push toward greater engagement for foreign legal systems, including their public law components. Thin "transnationalism" indeed, and little more than the simple application of international law, but notable in holding that such law forms part of the common law of the United States, at least under some circumstances. Notable, too, in that the issues left unanswered in Sosa are certain to return to the Supreme Court in the next couple of years.

In Boumediene, the government's detention of alleged enemy combatants at Guantanamo and their limited opportunity to contest their detentions, led the Court to consider whether the writ of habeas corpus provided for in the U.S. Constitution applied to aliens detained abroad. In adopting a "practical", multi-factored approach to this question, the Court at least suggested that in some circumstances the domestic legal system in the host country might be an appropriate consideration. ${ }^{9}$ This, I think, is ever thinner.

\footnotetext{
${ }^{4} 542$ U.S. $692(2004)$.

${ }^{5} 128$ S.Ct. 2229 (2008).

${ }^{6} 548$ U.S. 331 (2006).

${ }^{7} 128$ S.Ct. 1346 (2008).

${ }^{8}$ Sosa, 542 U.S. at 737.

${ }^{9}$ Boumediene, 128 S.Ct. at 2254.
} 
The Sanchez-Llamas and Medellin cases both considered the significance of an International Court of Justice judgment within the domestic U.S. legal system. The Court concluded that it was not bound by ICJ precedence in Sanchez-Llamas and that ICJ judgments are not directly enforceable in U.S. courts in Medellin. The Sanchez-Llamas opinion turns to comparative analysis as it considers whether it should follow the ICJ precedent out of "respectful consideration" for that tribunal and as it considers whether suppression is an appropriate remedy for a violation of the underlying treaty. ${ }^{10}$ Citing the differing nature of adversary and inquisitorial systems, the opinion concludes the ICJ's approach was inconsistent with the basic framework of U.S. - style adversary systems. The Medellin opinion looked to the practice of other countries, in particular their failure to treat ICJ judgments as directly enforceable, as support for its conclusion. ${ }^{11}$ The "transnational" aspects of these two cases are clearer, but they illustrate a final point with which I would like to end: transnationalism will not automatically lead to great efficacy or enforcement of international norms and law. Transnationalism, moreover, need not result in uniformity, and I think it is possible to support the former without necessarily the later. ${ }^{12}$ Thus, although Medellin and Sanchez-Llamas are generally seen as a defeat for the enforcement of international law, they are not necessarily defeats for some versions of transnationalism.

\footnotetext{
${ }^{10}$ Sanchez-Llamas, 548 U.S. at 343-44, 356-57; id. at 393-396 (Breyer, J. dissenting).

${ }^{11}$ Medellin, 128 S.Ct. at 1363.

${ }^{12}$ See Matthias Mahlmann's contribution to this special issue.
} 
[Vol. 10 No. 10 